\title{
WPROWADZENIE DO METODY SIX SIGMA
}

Streszczenie: Six Sigma to nowoczesny i bardzo rygorystyczny sposób zarządzania organizacjami, których celem jest dążenie do doskonałości. Metoda opiera się na TQM oraz ciągłym doskonaleniu. Cele artykułu było wprowadzenie czytelnika w podstawy metody Six Sigma. Na początku zdefiniowano pojęcie Six Sigma oraz opisano pochodzenie nazwy. Zestawiono etapy wdrażania metody Six Sgima w przedsiębiorstwie i zasady Six Sigma. Scharakteryzowano także projekt DMAIC.

Słowa kluczowe: jakość, Six Sigma, doskonalenie

\section{Wprowadzenie}

Ze względu na ciągle wymagania klientów i bardzo dużą konkurencję na rynku, przedsiębiorstwa szukają różnorodnych rozwiązań, aby przekonać do siebie klientów, produkując wyroby o jak najwyższej jakości. Jedną z metod, która w takiej sytuacji jest wykorzystywane, jest metoda Six Sigma.

Six Sigma to nowoczesny i bardzo rygorystyczny sposób zarządzania organizacjami, których celem jest dążenie do doskonałości. Metoda opiera się na TQM oraz ciągłym doskonaleniu. Jest to metoda, która mierzy proces pod względem wykrytych defektów. Jest nastawiona na redukcją wadliwości w procesach już istniejących, ale także może być wykorzystywana w projektowaniu nowych procesów.

Six Sigma, metoda mocno oparta na statystyce, technika podnoszenia jakości i efektywności procesów, jest dobrze znana i często stosowana w firmach na poziomie operacyjnym. Pomaga obniżać koszty, usprawniać procesy i skracać czas trwania cykli biznesowych [1].

Metoda Sig Sigma powstała w połowie lat 80. XX wieku w firmie Motorola. W 1988. W roku firma ta została odznaczona niezwykle prestiżową nagrodą Amerykańską Nagrodę Jakości im. M. Baldridge'a. Ponadto za potwierdzenie ponadprzeciętnej wartości (użyteczności i efektywności) tej metody uznać należy stale rosnącą liczbę światowej klasy koncernów i korporacji międzynarodowych stosujących tą koncepcję zarządzania przez jakość [2].

${ }^{1}$ Dr inż., Department of Production Engineering and Safety, Faculty of Management, Czestochowa University of Technology, Al. Armii Krajowej 19b, 42-200 Częstochowa, Polska, e-mail: manuela.ingaldi@wz.pcz.pl, ORCID ID: 0000-0002-9793-6299 
W literaturze istnieje wiele definicji metody Six Sigma. Na przykład Douglas i Erwin stwierdzili, że Six Sigma skupia się wokół klienta, a nie wokół produktu [3]. Według Evans i Lindsay Six Sigma to podejście poprawiające procesy biznesowe, które stara się znaleźć i wyeliminować przyczyny wad i błędów, skrócić czas cyklu i zmniejszyć koszty działalności równocześnie zwiększając wydajność i lepiej spełniając oczekiwania klientów [4]. Natomiast Brady i Allen twierdzą, że Six Sigma to poparte technikami statystycznymi, zorganizowane i systematyczne podejście do procesu doskonalenia, mające na celu obniżenie wskaźnika defektów [5]. Według Antony Six Sigma to systematyczna metodologia, która daje pracownikom statystyczne i niestatystyczne narzędzia i techniki, w celu uzyskania wiedzy na temat procesów i produktów krytycznych, niezbędnych do osiągania zarówno operacyjnej, jak i biznesowej doskonałości [6]. Należy podkreślić, że jednak trudno jest jednoznaczną, pełną i uniwersalną definicję, gdyż Six Sigma bardzo silnie oddziałuje z kulturą organizacyjną przedsiębiorstwa i w każdej firmie przyjmuje inną, zindywidualizowaną formę.

Najważniejszą cechą odróżniającą Six Sigmę od dotychczasowych metod zarządzania jakością jest zmiana podejścia do samej istoty i definicji pojęcia „jakość”, która od tej pory nie jest wartością samą w sobie [7]. Głównym celem Six Sigma jest poprawa jakości wyników procesu poprzez identyfikację i usunięcie przyczyn defektów oraz zminimalizowanie zmienności w procesach produkcyjnych i biznesowych. To filozofia biznesu nastawiona na cięcie kosztów, podnosząc jednocześnie satysfakcję klienta.

Mocną stroną koncepcji Six Sigma jest klarowny podział odpowiedzialności i obowiązków między pracownikami, szczegółowo określone wymagania stawiane kandydatom na dane stanowisko $\mathrm{w}$ strukturze organizacyjnej oraz rozbudowany system szkoleń $[8,9]$.

W przypadku Six Sigma tworzona jest specjalna struktura, składająca się z zespołów ludzi o różnych zasobach wiedzy i kwalifikacjach (tabela 1).

\section{Tabela 1. System pasów Six Sigmy z opisem petnionych funkcji udzial w strukturze organizacyjnej}

\begin{tabular}{|l|l|}
\hline $\begin{array}{l}\text { Rola w projekcie Six } \\
\text { Sigma }\end{array}$ & Pełnione funkcje \\
\hline Champion & $\begin{array}{l}\text { Członek ścisłego kierownictwa organizacji, którego } \\
\text { nadrzędnymi funkcjami są wspieranie wdrożenia projektów } \\
\text { Six Sigma i zagwarantowanie potrzebnych zasobów. }\end{array}$ \\
\hline
\end{tabular}




\begin{tabular}{|l|l|}
\hline $\begin{array}{l}\text { Master Black Belt (1 } \\
\text { na 10-20 Black Belt) }\end{array}$ & $\begin{array}{l}\text { Trenerzy i mentorzy Black Belt i Green Belt, odpowiedzialni } \\
\text { za opracowywanie kluczowych wskaźników i strategicznego } \\
\text { kierunku. Działa w organizacji jako technolog i konsultant } \\
\text { wewnętrzny. }\end{array}$ \\
\hline Black Belt(1\%-2\%) & $\begin{array}{l}\text { Liderzy zespołów, którzy odpowiadają za sprawne } \\
\text { funkcjonowanie projektów. Muszą posiadać dużą wiedzę na } \\
\text { temat metodologii Six Sigma oraz wnioskowania } \\
\text { statystycznego. }\end{array}$ \\
\hline $\begin{array}{l}\text { Green Belt(5\% } \\
10 \%)\end{array}$ & $\begin{array}{l}\text { Stanowią grupę asystentów wyższych pasów, czasami } \\
\text { prowadzą własne zespoły małych projektów. Głównie } \\
\text { przyczyniają się do analizowania i gromadzenia danych, które } \\
\text { są wykorzystywane do projektów. }\end{array}$ \\
\hline $\begin{array}{l}\text { Yellow Belt(25\% - } \\
50 \%)\end{array}$ & $\begin{array}{l}\text { Członkowie zespołu, realizujący zadania przydzielone przez } \\
\text { przełożonych. Dokonują przeglądu, analizy i propozycji } \\
\text { ulepszenia prowadzonych projektów }\end{array}$ \\
\hline
\end{tabular}

Source: [10]

\section{Dlaczego Six Sigma}

Six Sigma określa światowy standard zmienności charakteryzującej procesy, wyrażonej odchyleniem standardowym $\sigma$ (sigma) lub s, oznaczający, że w procesie można oczekiwać nie więcej niż 3,4 wad/błędów na milion możliwości ich wystąpienia. Podstawowym założeniem metody Six Sigma jest więc osiągnięcie poprawności produkcji na poziomie $99,997 \%$. Pozostałe $0,003 \%$ to właśnie $6 \sigma$, czyli sześciokrotna wartość odchylenia standardowego [11]. Tak wysoka jakość oferowanych wyrobów oraz usług przekłada się na znaczący wzrost konkurencyjności przedsiębiorstwa, a w konsekwencji na polepszenie jego rentowności $[12,13]$. Graficzna interpretacja prawa $6 \sigma$ została przedstawiona na rysunku 1. 


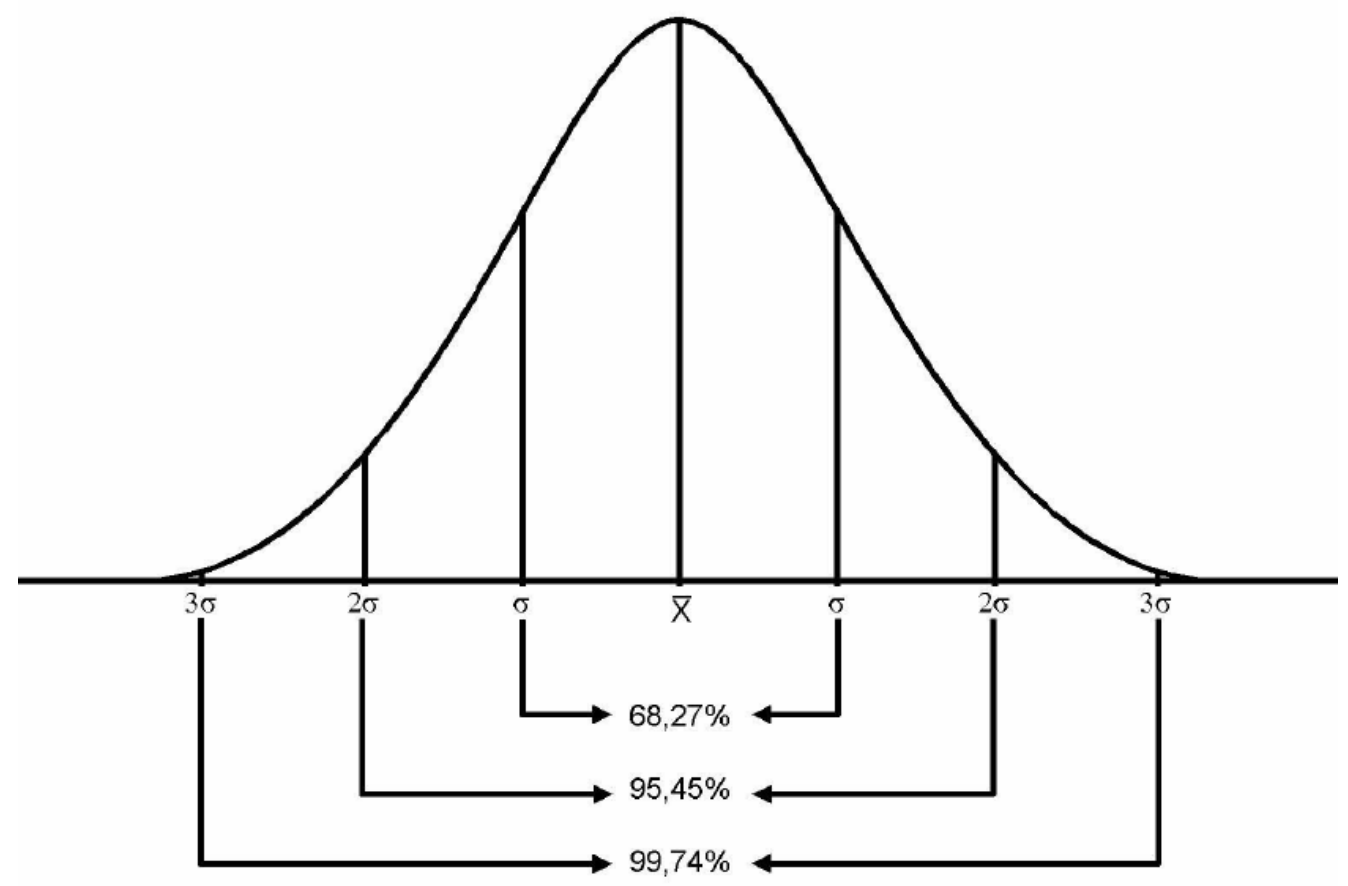

Rys. 1. Prawo $6 \sigma$

Źródto: [14].

Aby ocenić miarę rzeczywistą sprawności i stabilność procesu, należy wyznaczyć wskaźniki zdolności jakościowej procesu. Pierwszy wskaźnik zdolności jakościowej procesu, oznaczany w literaturze $\mathrm{Cp}$, wyraża zgodność jakościową procesu z uwzględnieniem jego sterowania. Pozwala określić zdolność procesu do wytwarzania produktów o stałych własnościach. Uwzględnia on tylko odchylenie procesu produkcyjnego. Wskaźnik $\mathrm{Cp}$ określa, ile razy przedział naturalnej zmienności danej cechy mieści się w polu tolerancji badanej cechy. Oblicza się go ze wzoru [15]:

$$
c_{p}=\frac{G L T-D L T}{6 s}=\frac{T}{6 s}
$$

gdzie:

GLT - górna granica tolerancji badanej cechy,

DLT - dolna granica tolerancji badanej cechy,

$\mathrm{T}$ - pole tolerancji,

$\mathrm{s}$ - odchylenie standardowe. 
Wskaźnik Cp przyjmie wartość powyżej 1, jeśli pole zmienności jest mniejsze od pola tolerancji. Jednak, aby zapobiec możliwości pojawienia się problemów, wartość wskaźnika powinna być większa od 1,44. Iwasiewicz [16] podaje następujący sposób interpretacji wskaźnika Cp:

- $\mathrm{Cp}<1$ - niska względna zdolność procesu,

- $\quad 1<\mathrm{Cp}<1,33$ - średnia względna zdolność procesu,

- $1,33<\mathrm{Cp}$ - wysoka względna zdolność procesu.

Wskaźnik $\mathrm{Cp}$ nie uwzględnia niestety usytuowania naturalnego przedziału zmienności procesu $\mathrm{w}$ danych granicach tolerancji, i nawet znacznie przesunięcie nie znajduje swego odzwierciedlenia w jego wartości [17]. Dlatego wskaźnik Cp należy uzupełnić o wskaźnik Cpk.

Wskaźnik Cpk to skorygowana postać wskaźnika Cp. Uwzględnia on zarówno naturalną zmienność cechy, jak i położenie jej wartości średniej w stosunku do granic tolerancji (do wartości nominalnej). Wskaźnik ten oblicza się ze wzoru [15]:

$$
\begin{aligned}
c_{p k}= & \frac{G L T-\bar{x}}{3 s} \text { jeśli } G L T-\bar{x} \leq \bar{x}-D L T \\
c_{p k}= & \frac{\bar{x}-D L T}{3 s} \text { jeśli } G L T-\bar{x}>\bar{x}-D L T
\end{aligned}
$$

gdzie:

GLT, DLT, s - jak poprzednio,

$\bar{x}$ - wartość średnia próby.

Wskaźnik Cp określa potencjalne możliwości procesu do spełnienia wymagań jakościowych. Natomiast Cpk jest miarą wycentrowania procesu. Wskaźnik Cpk dzięki swojej konstrukcji umożliwia określenie różnicy pomiędzy wartością średnią procesu a nominalnym poziomem przeciętnym.

Jeśli $\mathrm{Cp} \neq \mathrm{Cpk}$, to na proces działa stały czynnik powodujący, że średnia wartość badanej cechy jest różna od wartości nominalnej. Wskaźnik Cpk może być użyty, gdy mamy określoną tylko jedną wartość tolerancji, maksymalną lub minimalną. Nie można natomiast stosować wtedy wskaźnika Cp $[18,19]$.

Wszelkie wady i błędy produktu finalnego wynikają z niewłaściwego podejścia procesowego, w związku z czym należy je eliminować na każdym etapie procesu produkcyjnego [20]. Strategia Six Sigma okazała się dobrym rozwiązaniem, ponieważ jej ideą było i jest działanie prewencyjne. Bogactwo narzędzi, którymi dysponuje niniejsza metodyka pozwala na doskonalenie procesów na każdym etapie, przy czym największy nacisk kładziony jest na eliminowanie wad już w fazie projektu. 


\section{Wdrażanie Six Sigma}

Wdrażanie Six Sigma w przedsiębiorstwie jest procesem długotrwałym, trwa ok. 6 lat. Wymaga wysokich nakładów na kształcenie pracowników czy zmianę infrastruktury poszczególnych procesów. Etapy wdrażania zostały przedstawione w tabeli 2 .

Tabela 2. Etapy wdrażania koncepcji Six Sigma w organizacji rynkowej

\begin{tabular}{|c|c|c|}
\hline Etap & Cele etapu & Charakterystyka etapu \\
\hline 1 & $\begin{array}{l}\text { Stworzenie jasnego obrazu, } \\
\text { który pomoże zrozumieć } \\
\text { podstawowe, funkcjonalne } \\
\text { działania w organizacji oraz } \\
\text { ich wzajemnego } \\
\text { oddziaływania z klientami } \\
\text { zewnętrznym. }\end{array}$ & $\begin{array}{l}\text { Tworzenie mapy działań kreujących wartości w } \\
\text { organizacji powinno opierać się na } \\
\text { następujących pytaniach: } \\
\text { 1. Jakie procesy możemy uznać za główne bądź } \\
\text { tworzące wartość dodaną? } \\
\text { 2. Jakie produkty lub usługi dostarczane są } \\
\text { klientom organizacji? } \\
\text { 3. Jaki charakter mają sprzężenia wewnętrzne i } \\
\text { zewnętrzne (z otoczeniem) procesów } \\
\text { przebiegających w ramach organizacji? }\end{array}$ \\
\hline 2 & $\begin{array}{l}\text { Ustalenie standardów } \\
\text { wykonania, na podstawie } \\
\text { informacji napływających } \\
\text { od klientów w taki sposób, } \\
\text { aby wydajność procesów } \\
\text { mogła być dokładnie } \\
\text { mierzona oraz aby istniała } \\
\text { możliwość przewidywania } \\
\text { satysfakcji klientów. } \\
\text { Wprowadzenie lub } \\
\text { usprawnienie metod i } \\
\text { narzędzi ukierunkowanych } \\
\text { na zbieranie informacji } \\
\text { artykułowanych przez } \\
\text { klientów. }\end{array}$ & $\begin{array}{l}\text { Opracowanie czytelnego i wyczerpującego } \\
\text { opisu czynników wpływających na satysfakcję } \\
\text { klientów w odniesieniu do produktów i } \\
\text { procesów; opisów należy przygotować w dwóch } \\
\text { kategoriach: } \\
\text { 1. „oczekiwania w stosunku do wyjść” związane } \\
\text { z wyrobami lub usługami końcowymi, } \\
\text { 2. „oczekiwania w stosunku do usług'; opisujące } \\
\text { sposób i zakres, w jakim organizacja powinna } \\
\text { wchodzić w interakcje ze swoimi klientami. }\end{array}$ \\
\hline 3 & $\begin{array}{l}\text { Właściwa ocena wyników } \\
\text { każdego procesu w świetle } \\
\text { zdefiniowanych oczekiwań } \\
\text { klientów oraz opracowanie }\end{array}$ & $\begin{array}{l}\text { 1. Miary bazowe, czyli ilościowa ocena } \\
\text { bieżących wyników procesów. } \\
\text { 2. Miary wydajności - oszacowanie możliwości } \\
\text { procesów w zakresie spełniania oczekiwań. }\end{array}$ \\
\hline
\end{tabular}




\begin{tabular}{|c|c|c|}
\hline & $\begin{array}{l}\text { systemu pomiarów } \\
\text { kluczowych właściwości } \\
\text { wytwarzanych wyrobów i } \\
\text { świadczonych usług }\end{array}$ & $\begin{array}{l}\text { 3. System miar - nowe lub udoskonalone } \\
\text { metody i zasoby, pozwalające na } \\
\text { dokonywanie ciągłych ocen przez pryzmat } \\
\text { zorientowanych na klienta standardów w } \\
\text { zakresie wyników działalności. }\end{array}$ \\
\hline 4 & $\begin{array}{l}\text { Identyfikacja możliwości } \\
\text { dokonania usprawnień o } \\
\text { dużym potencjale oraz } \\
\text { zorientowanych procesowo } \\
\text { rozwiązań, wspierana } \\
\text { kreatywnym myśleniem i } \\
\text { aktualnymi informacjami. } \\
\text { Ponadto efektywne } \\
\text { wprowadzenie nowych } \\
\text { rozwiązań i procesów }\end{array}$ & $\begin{array}{l}\text { 1. Priorytety usprawnień. Potencjał projektów } \\
\text { Six Sigma oceniany jest na podstawie ich } \\
\text { wykonalności i skutków. } \\
\text { 2. Usprawnianie procesu. Rozwiązania } \\
\text { ukierunkowane na specyfikację przyczyn } \\
\text { źródłowych. } \\
\text { 3. Nowe lub przeprojektowane procesy. Nowe } \\
\text { działania lub przepływ pracy stworzony w } \\
\text { celu zaspokojenia potrzeb, wprowadzania } \\
\text { nowych technologii, wzrostu szybkości, } \\
\text { dokładności, jakości itp. }\end{array}$ \\
\hline 5 & $\begin{array}{l}\text { Zainicjowanie działań } \\
\text { biznesowych kierujących } \\
\text { usprawnianiem wyników } \\
\text { realizowanych procesów, } \\
\text { zapewniających ciągły } \\
\text { pomiar, } \\
\text { przeprowadzających } \\
\text { ponowne badania oraz } \\
\text { odnawiających produkty, } \\
\text { usługi, procesy i procedury. } \\
\text { Etap piąty to poziom, na } \\
\text { którym organizacja realizuje } \\
\text { wytyczne sformułowane w } \\
\text { założeniach systemu Six } \\
\text { Sigma }\end{array}$ & $\begin{array}{l}\text { 1. Kontrola procesu. Pomiary i monitorowanie } \\
\text { w celu podtrzymania działań } \\
\text { usprawniających. } \\
\text { 2. Przyporządkowanie i zarządzanie procesami. } \\
\text { 3. Plan odpowiedzi. Mechanizmy działań oparte } \\
\text { na kluczowych informacjach pozwalających } \\
\text { na doskonalenie produktów i procesów. } \\
\text { 4. Kultura Six Sigma. Ukierunkowanie } \\
\text { organizacji na ciągłe odnawianie wszelkich } \\
\text { aspektów związanych z jej funkcjonowaniem. } \\
\text { Narzędzia i zagadnienia związane z koncepcją } \\
\text { Six Sigma powinny stać się zasadniczą } \\
\text { częścią środowiska biznesowego. }\end{array}$ \\
\hline
\end{tabular}

Source: [21].

\section{Zasady Six Sigma}

Metoda Six Sigma działa według 6 zasad [22]:

- Zasada 1 - kierunek klient. Potrzeby klienta się zmieniają - trzeba je analizować na bieżąco i aktualizować bazę danych. Należy patrzeć dlaczego, i w jaki sposób przedsiębiorstwo może zidentyfikować potrzeby klientów, jak może je zmierzyć, 
jak może reagować na pojawiające się nowości oraz jakie są niezidentyfikowane, często niepowiedziane potrzeby.

- Zasada 2 - zarządzanie wykorzystujące informację. Nie podejmuj decyzji na podstawie opinii i założeń, tylko na podstawie danych i pomiarów. Należy określić wskaźniki pomagające zmierzyć poziom działania firmy, następnie zebrać i przeanalizować dane $w$ celu zrozumienia kluczowych zmiennych i zoptymalizowania rezultatów.

- Zasada 3 - proces, zarządzanie i ulepszanie. Proces nie jest złem koniecznym zachodzi tam, gdzie się coś dzieje; jest jednym z najważniejszych elementów koniecznych do osiągnięcia sukcesu.

- Zasada 4 - aktywne zarządzanie. Wykonywanie czynności zanim się coś wydarzy. To zbudowanie podstaw do kreatywnych i skutecznych zmian.

- Zasada 5 - nieograniczona współpraca. Łańcuch dostaw - potrzeby klientów. Wymaga zrozumienia rzeczywistych potrzeb końcowych użytkowników, jak i przepływu pracy $\mathrm{w}$ całym procesie. To tworzenie środowiska oraz struktury zarządzania umożliwiającej faktyczną pracę zespołową.

- Zasada 6 - doskonałość, tolerancja dla niepowodzeń. Ciągłe samodoskonalenie oraz zaakceptowanie - od czasu do czasu - niepowodzeń, z którymi należy umieć sobie poradzić.

\section{Projekt DMAIC}

DMAIC to metoda wdrażania udoskonaleń biznesowych i redukowania kosztów. Polega na doskonaleniu procesu opartym na cyklu Deminga, będącym spójnym algorytmem doskonalenia jakości w wielu obszarach funkcjonowania przedsiębiorstwa. Jest usystematyzowanym i rygorystycznym podejściem do doskonalenia procesu, składającym się z pięciu faz [23].

Fazy Six Sigma to $[22,24,25]$ :

- Define (definiuj) - określenie problemu, odnalezienie procesu wymagającego przeprowadzenia projektu, wyznaczenie cech krytycznych dla jakości.

- Measure (mierz) - pomiar procesu oraz ustalenie i sprawdzenie systemu mającego służyć pomiarowi procesu w celu uzyskania potrzebnych danych.

- Analize (analizuj) - analiza otrzymanych danych służąca ustaleniu najistotniejszych, mających wpływ na zdefiniowaną wcześniej cechę krytyczną faktorów.

- Improve (poprawiaj) - czynności mające na celu zapewnienie stwierdzonym elementom wymaganych wartości.

- Control (nadzoruj) - monitorowanie stałości rozwiązań. 
W tabeli 3 dokonano charakterystyki poszczególnych faz procesu DMAIC. Uwzględniono etapy danej fazy oraz narzędzia i metody, które mogą być w danej fazie wykorzystywane.

Tabela 3. Charakterystyka faz procesu DMAIC

\begin{tabular}{|c|c|c|}
\hline Etap & Etapy & Narzędzia i metody \\
\hline Definiuj & $\begin{array}{ll}\text { Należy zdefiniować: } \\
-\quad \text { wymagania klientów, } \\
-\quad \text { główne cele przedsięwzięcia/ projektu, } \\
-\quad \text { zakres odpowiedzialności } \\
\text { poszczególnych zespołów, } \\
-\quad \text { zasoby niezbędne do zrealizowania } \\
\text { projektu, } \\
-\quad \text { mapę rozwoju, dostawców, wejścia, } \\
\text { procesy, produkcję i klientów (SIPOC), } \\
\text { - } \\
\text { przebiegi procesów. }\end{array}$ & $\begin{aligned}- & \text { diagramy Pareto, } \\
- & \text { diagramy } \\
& \text { podobieństwa, } \\
- & \text { schematy przebiegu } \\
& \text { procesu, } \\
- & \text { analiza FMEA. }\end{aligned}$ \\
\hline Mierz & $\begin{array}{l}\text { Do najważniejszy należą: } \\
\text { - } \quad \text { decyzje dotyczące oceny wejść, } \\
\text { procesów i wyjść, } \\
\text { - } \\
\text { - } \\
\text { plan gromadzenia danych, } \\
\text { wożidację skutków i analiza } \\
\text { - } \\
\text { ocenę zdolności procesu. }\end{array}$ & $\begin{array}{ll}- & \text { MSA, } \\
- & \text { SPC, } \\
- & \text { wykresy trendów. }\end{array}$ \\
\hline Analizuj & $\begin{array}{l}\text { Następujące procesy: } \\
\text { _ } \quad \text { analiza wejście - proces - wyjście } \\
\quad \text { (IPO), } \\
\text { - } \\
\text { analiza strumienia procesu w celu } \\
\text { identyfikacji problemów występujących } \\
\quad \text { w trakcie danego procesu, } \\
-\quad \text { poprawa procesu w celu } \\
\quad \text { wyeliminowania błędów, } \\
\text { - } \\
\text { zatwierdzenie zmian w procesie. }\end{array}$ & $\begin{array}{ll}- & \text { diagram Ishikawy, } \\
- & \text { histogramy, } \\
- & \text { metoda 5-why, } \\
- & \text { DOE (Design of } \\
& \text { Experiments), } \\
- & \text { analiza regresji. }\end{array}$ \\
\hline Poprawiaj & $\begin{array}{l}\text { Następujące czynności: } \\
\text { - określenie kolejnych rozwiązań } \\
\text { mających na celu poprawę } \\
\text { funkcjonowania procesu, } \\
\text { - } \quad \text { prezentacja zaleceń dotyczących } \\
\quad \text { wprowadzania poszczególnych } \\
\quad \text { rozwiązań, } \\
\end{array}$ & $\begin{array}{ll} & \text { burza mózgów, } \\
- & \text { Poka Yoke, } \\
- & \text { diagramy procesów, } \\
- & \text { macierze działań } \\
& \text { korygujących. }\end{array}$ \\
\hline
\end{tabular}




\begin{tabular}{|l|l|l|}
\hline & - wprowadzenie zmian w życie. & \\
\hline Nadzoruj & Podczas etapu sprawdzania monitoruje się & - plany kontroli, \\
& wyniki osiągnięte w poprzednim etapie. & - metodyka SPC, \\
& & - metoda FMEA, \\
& & $-5 \mathrm{~s}$. \\
\hline
\end{tabular}

Source: $[26,27]$

\section{Podsumowanie}

Six Sigma to skuteczne podejście do szeroko zakrojonego programu kontroli jakości. To znacznie więcej niż tradycyjne podejście, w którym wewnętrzne zespoły są tworzone w celu zmniejszenia defektów produkcyjnych, rozwiązywania problemów w ramach jednego działu. Six Sigma to więcej niż program kontroli jakości o innej nazwie; jest to oparty na jakości system reorganizacji całego podejścia do pracy $\mathrm{w}$ każdym aspekcie: produktywności, komunikacji, zaangażowania na każdym poziomie i usług zewnętrznych.

Wdrożenie Six Sigma jest procesem długotrwałym i wymaga od przedsiębiorstwa dokonania radykalnych zmian. O powodzeniu wprowadzania tych zmian decydują pracownicy oraz ich nastawienie. Nie będzie działać dobrze bez poświęcenia i przekonania najwyższego kierownictwa. Wymaga także dużych nakładów.

Six Sigma zmienia sposób myślenia firmy poprzez nauczanie podejmowania decyzji opartych na faktach na wszystkich poziomach. Program zmienia „DNA” firmy, zmieniając sposób myślenia liderów i ulepszając proces zarządzania poprzez rozwijanie umiejętności zarządzania i komunikacji u ludzi [28].

\section{Bibliografia}

[1] Osiadacz J.: Narzędzia identyfikacji potrzeb innowacyjnych $w$ przedsiębiorstwach. Polska Agencja Rozwoju Przedsiębiorczości, Warszawa 2011.

[2] Nowicki M.: Six Sigma [w:] Kompendium metod i technik zarzadzania. Technika i ćwiczenia. K. Szymańska (red.), Oficyna a Wolters Kluwer business, Warszawa 2015, s. $284-315$

[3] Douglas P.C., Erwin J.: Six Sigma's focus on total customer satisfaction. Journal for Quality and Participation, 2000, Vol. 23, No 2, 45-49.

[4] Evans J.R., Lindsay W.M.: The Management and Control of Quality. South-Western, Mason, OH, 2005.

[5] Brady J.E., Allen T.T.: Six Sigma literature: a review and agenda for future research. Quality and Reliability Engineering International, 2006, 22, s. 335-367. 
[6] Antony J.: Six Sigma: a strategy for supporting innovation in pursuit of business excellence. International Journal of Technology Management, 2007, 37.

[7] Hamrol A.: Strategie $i$ praktyki sprawnego działania. Lean, Six Sigma $i$ inne. Wydawnictwo Naukowe PWN, Warszawa, 2015.

[8] Bogacz P., Mizga M.: Zastosowanie Lean Six Sigma w doskonaleniu procesów produkcyjnych $w$ przemyśle wydobywczym. Inżynieria Mineralna, Lipiec - Grudzień 2016, s. 23-29.

[9] Torczewski K.: Six Sigma - czym jest i co może przynieść Twojej organizacji? [w]: Six Sigma Międzynarodowa Konferencja. Wrocławskie Centrum Transferu Technologii, Wrocław, 2004.

[10]Zhang W., Hill A. V., Gilbreath G1. H.: A research Agenda for Six Sigma Research. QMJ, 2011, Vol.18, No1, s. 39-53.

[11]Eckes G.: Rewolucja Six Sigma - jak General Electric i inne przedsiębiorstwa zmienity proces $w$ zyski. MT Biznes, Warszawa, 2010.

[12] Knop K.: Statistical control of the production process of rolled products. Production Engineering Archives, 2018, 20, s.26-31.

[13] Kowalik K.: Six Sigma as a method of improving the quality of service process. Production Engineering Archives, 2018, 19, s. 10-15.

[14] [http://strefaqm.pl/statystyczne-sterowanie-procesem-spc/ (odczyt 12.03.2019).

[15] Hamrol A., Mantura W.: Zarządzanie jakością. Teoria i praktyka. Wydawnictwo Naukowe PWN, Warszawa 2002.

[16] Iwasiewicz A.: Zarządzanie jakością. Wydawnictwo Naukowe PWN, Warszawa Kraków, 1999.

[17] Smoliński A., Szymszal J., Gajda J.: Wykorzystanie analizy wskaźników zdolności do optymalizacji procesu wytwarzania masy formierskiej. Archiwum Odlewnictwa, Rok 2006, Rocznik 6, Nr 18 (2/2), s. 515-520.

[18] Maleszka A., Zalewski R.: Quality - zarzadzanie jakością. Centrum Kreowania Liderów, Skierniewice 1995.

[19] Ingaldi M. Process Capacity Indexes in the Production of Ribbed Bars. [w:] 26th Anniversary International Conference on Metallurgy and Materials (METAL 2017), Brno, Czechy Conference proceedings, Tanger Ostrava 2017, s. 2164-2169.

[20] Gupta P.: Six Sigma Business Scorecard. The McGraw-Hill Companies, NY, 2004.

[21] Doroszewicz S., Tyszkiewicz A.: Systemowe podejście do zarzadzania jakościa wedtug koncepcji Six Sigma. Studia i Prace Kolegium Zarządzania i Finansów. Zeszyt Naukowy, 2017, Nr 158, s. 157-178.

[22] Lis M., Ratajczak S.: Six Sigma jako metoda doskonalenia jakości przedsiębiorstw w okresie rosnącej globalizacji. ZN WSH Zarządzanie, 2014, 2, s. 45-58.

[23] Gołębiowski M.: DMAIC i DMADV jako metody doskonalenia jakości. STUDIA I Prace Wydziału Nauk Ekonomicznych I Zarządzania, 2011, Nr 21, s. 135- 141.

[24] Grudowski P., Leseure E.: LSS Plutus. Lean Six Sigma dla matych i średnich przedsiębiorstw. Wydawnictwo WNT, Warszawa, 2013. 
[25] Grudowski P., Leseure E., BigandM., Castelain E.: Wykorzystanie metodyki LeanSix Sigma $w$ doskonaleniu funkcjonowania małych i średnich przedsiębiorstw. Zarządzanie i Finanse, 2012, R. 10, nr 3, cz. 3, s. 29-41.

[26] Basu R., Wright J. Quality Beyond Six Sigma. Butterworth-Heinemann, Oxford, 2003.

[27] McCarty Th., Bremer M., Daniels L. , Gupta P.: The Six Sigma Black Belt Handbook. The McGraw-Hill Companies, NY 2004.

[28] Fursule N.V., Bansod S.V., Fursule S.N.: Understanding the Benefits and Limitations of Six Sigma Methodology. International Journal of Scientific and Research Publications, Volume 2, Issue 1, January 2012. s.1-9.

\title{
INTRODUCTION TO THE SIX SIGMA METHOD
}

\begin{abstract}
Six Sigma is a modern and very rigorous way of managing organizations which aim is to strive for excellence. The method is based on TQM and continuous improvement. The purpose of the paper was to introduce the reader to the basics of the Six Sigma method. At the beginning, the term Six Sigma was defined and the origin of the name was described. The stages of Six Sigma implementation in the company and Six Sigma principles have been summarized. The DMAIC project was also characterized.
\end{abstract}

Key words: uuality, Six Sigma, improvement

Data przestania publikacji do Redakcji: 22.04.2019 Data akceptacji publikacji przez Redakcję: 12.06.2019

DOI: 10.30657/qpi.2019.10.10 